\author{
Sławomir Stasiak \\ ORCID: 0000-0002-0949-2043 \\ Papieski Wydział Teologiczny we Wrocławiu \\ gimel@poczta.onet.pl
}

\title{
Symbolika krwi a bezkrwawa dieta w Starym i Nowym Testamencie i jej wpływ na styl życia. Aspekty prawne
}

Artykuł nadesłany: 4 czerwca 2018 r.; artykuł zaakceptowany: 6 września 2018 r.

JEL Classification: I 10

Keywords: Old Testament, New Testament, blood, symbolism of blood, lifestyle

\section{Abstract \\ The symbolism of blood and a bloodless diet in the Old and New Testament and its impact on lifestyle: Legal aspects}

The Old Testament prohibition of consuming blood (Lev. 17:10-14) was dictated by the observation of the phenomenon of blood loss as a cause of death of a human being. Therefore, blood was considered to have life-giving power, the power of God Himself. Blood flowing in the veins of every creature was considered to be God's property and was not allowed to be consumed, but it had to be poured out on the ground. In New Testament times, this prohibition was relativized, recommending only its preservation (Acts 15:28-29). Since there are also religious groups today that demand that we refrain from the consumption of blood, we decided to study the issue based on the texts of the Old and New Testament, which contain information about blood and its symbolism, as well as the prohibition of its consumption. The methods of contextual analysis and historical-critical analysis were applied.

As a result of these studies, it turned out that blood, especially in the Old Testament texts, has very extensive symbolism, which is why one can speak of the firstborn's blood, substitute blood, blood of the Covenant. Blood also played a special role in the worship of Israel, especially in sacrificial offerings. This meaning is also found in the New Testament: "without the shedding of blood there is no forgiveness of sins" (Heb. 9:22).

In the Old Testament, there are a number of texts in which the prohibition of consumption of blood has been imposed (see Gen. 9:4; Lev. 3:17; 7:26-27; Deut. 12:23), although refraining from eating meat in which blood would still be found is not always explicitlly mentioned. The most com- 
prehensive information on this subject, along with the justification of the prohibition, is included in Leviticus 17:10-14. Such prohibitions resulted in a specific lifestyle, and even slaughtering of animals, which was the subject of a large-scale social discussion.

We ask ourselves the question: Does this prohibition apply to today's Hebrews, Christians, or other social groups for whom the Bible is a peculiar norm of conduct? While the positive answer undoubtedly concerns the followers of Judaism, the issue of Christians is not so obvious. This is indicated by the so-called Jerusalem Council: "you abstain from what has been sacrificed to idols, and from blood, and from what has been strangled, and from sexual immorality. If you keep yourselves from these, you will do well. Farewell" (Acts 15:28-29). Three facts are of crucial importance here. First, these clauses were disciplinary and not doctrinal. Second, they had limited territorial coverage (see Acts 15:23). Third, one sentence is of particular significance in this context: "If you keep yourselves from these, you will do well" (Acts 15:29), which indicates this was not a warrant for salvation, but a recommendation to facilitate the faithful's life in mutual consent in a church made up of Christians of Jewish and pagan origin.

\section{Wstęp}

W ostatnich latach zarówno w mediach, jak i w salach sądowych toczyła się ożywiona dyskusja na temat uboju rytualnego i związanych z nim interesów z jednej strony religijnych (dieta wyznawców judaizmu i islamu), a z drugiej strony etycznych (obrońcy zwierząt). Postanowiłem się zająć w niniejszym artykule nie tyle zagadnieniami prawnymi w obecnym stanie rzeczy, ile poszukać korzeni takich właśnie zachowań zwłaszcza wyznawców judaizmu, dla których wiążącym prawem są przepisy zawarte w pierwszych pięciu księgach Starego Testamentu (Tora). Poza tym, będąc z jednej strony duchownym katolickim, a z drugiej strony biblistą, chciałem sięgnąć do Starego i Nowego Testamentu, szukając tam właśnie danych na temat bezkrwawej diety. Podejmując to zagadnienie i jego wpływu na styl życia człowieka, musimy najpierw przyjrzeć się zagadnieniu symboliki krwi zarówno w Starym, jak i w Nowym Testamencie. Według norm Starego Testamentu obowiązywał całkowity zakaz spożywania krwi i mięs ją zawierających. Zakaz ten był obwarowany bardzo surowymi regulacjami prawnymi. W czasach Nowego Testamentu, zwłaszcza w normach prawnych zawartych w postanowieniach tak zwanego Soboru Jerozolimskiego (około 50 r. po Chr.), ów zakaz wydaje się podtrzymany. Jednak to dokładna analiza tekstów zawierających owe normy pozwoli na odpowiedzieć na ptytanie o obowiązywalność tych rozporządzeń we współczesnym świecie.

\section{Symbolika krwi}

Krew jest symbolem oczyszczenia, ofiary; proroctwa, wtajemniczenia; przymierza, braterstwa; poświęcenia, męczeństwa, odkupienia; słabości; tabu, czarów, magii, obrony przed demonami; natury, Słońca, ognia, życia, duszy, temperamen- 
tu, namiętności, pociągu płciowego; płodności, potomstwa; zdrowia; usposobienia, charakteru, przyzwyczajenia; winy; pochodzenia, rasy, rodu, pokrewieństwa; króla, lwa, złota, wojny, morderstwa, pożywienia zmarłych ${ }^{1}$.

\section{A. Krew w Starym Testamencie}

W najstarszych religiach krew uchodziła za symbol życia. Utrzymywano nawet, że krew zawiera życie, rodzi życie, a poniekąd jest samym życiem. Przekonanie to opierało się na obserwacji ludzi pierwotnych, w której wyniku dochodzono do oczywistego wniosku, że utrata krwi w organizmie ludzkim lub zwierzęcym równała się utracie samego życia. A ponieważ życie uważano za wyłączną własność samego Boga, dlatego istniał zakaz jej spożywania. Odbicie tych przekonań w całej rozciągłości odnajdujemy w księgach biblijnych, w których między innymi czytamy: „Ale się wystrzegaj spożywania krwi, bo we krwi jest życie, i nie będziesz spożywał życia razem z ciałem" (Pwt 12,23; por. Rdz 9,4-5; Kpł 12,11-14). Przepisu tego trzymał się niemal ściśle jeszcze Kościół apostolski (Dz 15,20.29; 21,25).

W niektórych jednak religiach plemion prymitywnych istniał zwyczaj picia krwi ofiarowanego zwierzęcia, co miało służyć wzmocnieniu własnych sił życiowych mocą samego bóstwa.

1. Krew w kulcie izraelskim. Krew miała bardzo rozległe zastosowanie w izraelskich praktykach kultowych, a jej rozlanie podczas składania ofiary stanowiło istotny jej element. Za jej pośrednictwem Izraelita z jednej strony oddawał cześć Bogu, a z drugiej szukał dla siebie pomocy duchowej i moralnej i stąd jej charakter ofiarniczy i sakramentalny.

W aspekcie ofiarniczym uznawano, że ponieważ krew jest własnością Boga, dlatego należało $\mathrm{Mu}$ ją oddać z powrotem w akcie religijnym i w ten sposób wyrażano dla Niego istotną cześć religijną. Wylewano ją więc na ołtarz lub na jego podstawę, a gdy uboju zwierzęcia dokonywano w celach użytkowych, mieszano ją z ziemią, aby w ten sposób przeszkodzić w jej znieważeniu.

W aspekcie sakramentalnym, odnoszącym się do zbawienia człowieka, krew stanowiła środek dany przez Boga na oczyszczenie grzechów. „Bo życie ciała jest we krwi, a ja dopuściłem ją dla was [tylko] na ołtarzu, aby dokonywała przebłagania za wasze życie, ponieważ krew jest przebłaganiem za życie” (Kpł 17,11). Ta zasada odnosiła się w Starym Testamencie do wszystkich ofiar krwawych bez wyjątku, gdyż chociaż niektóre ofiary krwawe nie zakładały sobie celu zadośćuczynnego i wprost go nie wyrażały, to go jednak nie wykluczały. Zawsze ofiarowana krew usuwała bowiem z osoby lub rzeczy jakiś brak moralny i zastępowała go elementem dobra, tak że osoba lub rzecz, poprzednio Bogu niemiła lub mniej miła, stawała się znów pełną wartością wobec Niego.

\footnotetext{
1 W. Kopaliński, Słownik symboli, Warszawa ${ }^{2} 1990$, s. 168 b.
} 
Wyraz tego przekonania znajdujemy także w późniejszej literaturze judaistycznej. W Talmudzie Babilońskim czytamy, że „bez krwi nie ma pojednania”. Na tym samym stanowisku stoi Nowy Testament: „I prawie wszystko oczyszcza się krwią według Prawa, a bez przelewu krwi nie ma oczyszczenia [grzechów]" (Hbr 9,22). Uzasadnienie tego przekonania jest następujące: grzech osłabia człowieka i pozbawia go sił moralnych, krew natomiast zawiera życiodajną siłę i dlatego w akcie religijnym wzmacnia ofiarującego, oczyszcza go i uświęca.

2. Krew pierwszej paschy w Egipcie. Już na podstawie tych refleksji możemy wnioskować, że cały obrzęd pierwszej Paschy egipskiej był jednocześnie ofiarą i ucztą ofiarniczą, a krew zabitego baranka zawierała wszelkie znamiona ofiarnicze i sakramentalne. Rozważmy to bardziej szczegółowo.

a) Odłączenie baranka. Kiedy zbliżała się godzina wyjścia Izraelitów z Egiptu, Mojżesz z nakazu Bożego wydał następujące polecenie: „Dziesiątego dnia tego miesiąca niech postara się każdy o jagnię dla rodziny, o jagnię do domu [...]. Będziecie je strzec aż do czternastego dnia tego miesiąca, a wtedy zabije je całe zgromadzenie Izraela o zmierzchu" (Wj 12,3.6). Przepis ten dotyczył wyłącznie tej jednorazowej Paschy w Egipcie i nadawał barankowi charakter sakralny, gdyż przez wyłączenie go ze stada i z codziennych kontaktów czynił go sposobnym na ofiarę dla Boga.

Późniejsza tradycja judaistyczna niejednokrotnie komentowała ten szczegół. Według niej zamknięcie baranka miało rzekomo nastraszyć Egipcjan, a umocnić na duchu Izraelitów. Baranek według wierzeń Egipcjan zażywał bowiem boskiej czci, a nawet widziano w nim wcielenie bóstwa. Zamknięcie baranków przez Izraelitów było dowodem słabości ich bóstw, skoro pozwoliły się ujarzmić przez znienawidzonych nomadów. Izraelici zaś manifestowali przez to swoje zerwanie z egipskimi bogami, którym po części oddawali wówczas cześć, a przez to zdobyli zasługi przed swoim Bogiem, od których także do pewnego stopnia zależało ich wybawienie. Fakt ten uzmysławiał im, że wyzwolenie opiera się przede wszystkim na zwycięstwie ich Boga Jahwe nad bóstwami pogańskimi: „Tej nocy przejdę przez Egipt, zabiję pierworodne w ziemi egipskiej od człowieka aż do bydła, i odbędę sąd nad wszystkimi bogami Egiptu" (Wj 12,12).

b) Ślady krwi baranka. Istotną przyczyną ocalenia i wybawienia narodu z niewoli było wylanie krwi baranka i pomazanie nią progów i odrzwi domów izraelskich. Krew ta była znakiem ochronnym, a jego siła pochodziła stąd, że sam Bóg go ustanowił i związał z nim szczególne łaski dla Izraelitów: „Krew będzie wam służyła na oznaczenie domów, w których będziecie przebywać. Gdy ujrzę krew, przejdę obok i nie będzie pośród was plagi niszczycielskiej, gdy będę karał ziemię egipską" (Wj 12,13; por. Wj 12,23.27). Akt woli Bożej był tu gwarancją ocalenia i wskutek tego znak krwi widniejącej na progach i odrzwiach domów był dla Izraelitów do pewnego stopnia sakramentem. A ponieważ ofiarę baranka paschalnego miano powtarzać rokrocznie, dlatego też była ona sakramentem i dla następnych pokoleń.

c) Krew a pierworodni. Ocalenie to odnosiło się wówczas przede wszystkim do pierworodnych synów Izraela. Syn pierworodny był w przekonaniu najstar- 
szych plemion semickich „najcenniejszym potomstwem” (Mdr 18,12), należał do najbardziej umiłowanych (Rdz 22,2), był uważany za najdroższego i najdzielniejszego wśród wszystkich innych, gdyż uchodził za wcielenie męskiej siły rodzica (Rdz 49,3). Uświęcał on każdą rodzinę jako jej reprezentant i jako widomy znak błogosławieństwa Bożego, od którego zależało jej szczęście. A ponieważ Bóg ocalił ich wówczas za pośrednictwem rozlanej krwi, dlatego też należeli oni ściśle do Niego jako Jego własność, więc Izraelici musieli złożyć za nich Bogu okup, jeżeli chcieli ich sobie przywłaszczyć z powrotem (Lb 18,16).

Ponieważ synowie pierworodni byli podporą całego narodu, jego najszlachetniejszą cząstką, dlatego pośrednio ich ocalenie dotyczyło ocalenia całej jego egzystencji. Że istotnie został wówczas ocalony cały Izrael, to wynika choćby stąd, że owej pamiętnej nocy, kiedy anioł zniszczenia przechodził przez ziemię egipską, nie wolno było żadnemu Izraelicie opuszczać swojego domu aż do rana (Wj 12,22). Tym samym i cały naród stał się wówczas szczególną własnością Boga jako przez Niego ocalony z grożącej mu powszechnej klęski.

d) Krew zastępcza. W związku z tym ocaleniem zachodzi zasadnicze pytanie: czy przelana wówczas krew miała charakter zastępczy? Księga Wyjścia wprost nie potwierdza tej myśli, ale sugeruje ją sam opis tego zdarzenia paschalnego. Krew widniejąca na domach miała bowiem być nie tylko znakiem dla anioła zniszczenia, by je ominął, lecz także świadectwem, że ich mieszkańcy są ścisłą własnością Boga. Krew ta nie miała jednak charakteru zadośćuczynnego, gdyż z tekstu księgi bynajmniej nie wynika, by pierworodni, a z nimi cały naród, popełnili jakieś winy, za które należałoby ich ukarać śmiercią. Owa klęska miała bowiem charakter powszechny, a więc miała dotknąć wszystkich — nie tylko Egipcjan.

Nie można jednak całkowicie wykluczyć charakteru zadośćuczynnego pierwszej Paschy egipskiej, gdyż w kulcie izraelskim krew miała zawsze wprost lub pośrednio znaczenie oczyszczające. Wynika to ponadto z owej szczególnej opieki, jaką Bóg od tego właśnie momentu począł roztaczać nad całym narodem. Nie tylko bezpiecznie wyszedł on z niewoli, lecz po przekroczeniu Morza Czerwonego spotkał się także $\mathrm{z}$ widomą obecnością Boga w postaci obłoku w ciągu dnia, a w nocy - słupa ognistego, który ich prowadził (Wj 13,21). Że Bóg rzeczywiście oczyścił wówczas wszystkich Izraelitów z grzechów, wynika to z wymienionego przez Księgę Wyjścia 12,12 „hizopu”, którym miano pokropić progi i odrzwia domów. Hizop w religii izraelskiej uchodził bowiem zawsze za symbol oczyszczenia z grzechów (por. Ps 51,9).

e) Krew Przymierza. Przymierze między Bogiem a narodem odgrywało $\mathrm{w}$ religii izraelskiej istotną rolę. Znajdowało się ono w centrum zainteresowania niemal wszystkich autorów Ksiąg Starego Testamentu, a zwłaszcza Pięcioksięgu. W związku z tym wszyscy i wszystko w narodzie musiało być kierowane ku Bogu i stąd też wspólnym mianownikiem wszystkich ofiar krwawych było przywrócenie lub naprawienie Przymierza. Pieczęcią tego Przymierza była krew ofiarna. Szczególną funkcję pełniła ona przy zawieraniu Przymierza pod Synajem (Wj 24,5-8), trzy miesiące po wyruszeniu z Egiptu (Wj 19,1-24,18). Właściwie

Ekonomia - Wroclaw Economic Review 24/4 (2018)

(C) for this edition by CNS 
już Pascha egipska była zawarciem Przymierza, pod Synajem jednak zostało ono proklamowane w sposób uroczysty i z ustaleniem warunków, które Izraelici świadomie przyjęli. Tam to po złożeniu „ofiary całopalnej i ofiary biesiadnej z cielców” (Wj 24,5) Mojżesz wziął krew cielca, z której jedną częścią skropił ołtarz, a drugą lud, wymawiając nad nim następujące słowa: „Oto krew przymierza, które Jahwe zawarł z wami na podstawie wszystkich tych słów" (Wj 24,8). Po tym obrzędzie Mojżesz wraz z Aaronem i starszymi ludu mógł stanąć przed Bogiem, a cały lud został dopuszczony do spożycia uczty. „Na wybranych synów Izraela nie podniósł swej ręki, mogli przeto patrzeć na Boga. Potem jedli i pili” (Wj 24,11).

Obrzęd ten był do pewnego stopnia wspólnym uczestnictwem Boga i ludu izraelskiego w tej samej krwi, przedstawionym w sposób rytualno-symboliczny, dzięki któremu nastąpił ścisły związek wewnętrzny między Bogiem a narodem. „Teraz jeśli pilnie słuchać będziecie głosu mego i strzec mojego przymierza, będziecie szczególną moją własnością pośród wszystkich narodów, gdyż do mnie należy cała ziemia. Lecz wy będziecie mi królestwem kapłanów i ludem świętym" (Wj 19,5-6). Tak więc Pascha egipska i Przymierze zawarte pod Synajem stały się dwoma ogniskami, wokół których będą się koncentrować wszystkie opowiadania Księgi Wyjścia i do pewnego stopnia całego Pięcioksięgu. Zobaczymy też, że te dwa zdarzenia otrzymają pełną realizację typologiczną podczas Ostatniej Wieczerzy, kiedy to Jezus jako nowa Pascha - Baranek przelewający Krew w sposób misteryjny — da początek Nowemu Przymierzu.

Nietrudno zauważyć, że między Paschą egipską a Przymierzem pod Synajem istniał ścisły związek. Nawet od strony opisowej te dwa zdarzenia tworzą widoczną całość literacką. Najbliższym celem wychodzących Izraelitów z Egiptu było właśnie bowiem to, by znaleźć się pod Synajem; górą obecności Bożej (Wj 3; 19; 24; $1 \mathrm{Krl} 19)$, gdzie miały się dokonać uroczyste zaślubiny Boga z Izraelem. Jednak wstępnym aktem tej uroczystości była noc paschalna w Egipcie, w której już widać elementy strukturalne przyszłego Przymierza. Izrael już wówczas stał się społecznością Bożą, gdyż musiał spełnić wstępne warunki, które mu pozwoliły wejść w ścisły kontakt z Bogiem. Pod Synajem warunkiem zawarcia Przymierza było uroczyste zobowiązanie się ludu do wypełnienia przykazań, wypisanych na kamiennych tablicach; w Egipcie zaś Izraelici musieli zabić baranki i ich krwią pokropić odrzwia i progi swoich domów. Pod Synajem pieczęcią Przymierza była krew cielca, natomiast w Egipcie krew baranków była jakby ceną, na mocy której Bóg postanowił związać się ze swym ludem i wyprowadzić go bezpiecznie pod górę Synaj. Pod Synajem Przymierze zostało uroczyście ogłoszone, w Egipcie zaś Izraelici uświadomili sobie, że stanowią własność ich Boga Jahwe, który ma względem nich szczególne zamiary².

2 Punkty A i B zostały opracowane na podst. J. Drozd, Ostatnia Wieczerza nowa Pascha (Attende Lectioni IV), Katowice 1977, s. 45-51. 


\section{B. Krew w Nowym Testamencie}

W Nowym Testamencie termin „krew” (gr. haima) występuje 97 razy. Z tego 22 w Ewangeliach Synoptycznych, 6 w J, 12 w Corpus Paulinum, 21 w Liście do Hebrajczyków, 6 w Listach Powszechnych i 19 razy w Apokalipsie.

Uwięzienie człowieka w tym wszystkim, co ziemskie, dochodzi do głosu dość wyraźnie w formule „,ciało i krew”. Piotr, o tym że Jezus jest Mesjaszem, dowiedział się nie od ciała i krwi, czyli nie na drodze czysto ludzkiego rozumowania, lecz objawił mu to Ojciec, który jest w niebie (Mt 16,17). Ponieważ ciało i krew są ziemskiego pochodzenia, nie mogą posiąść królestwa Bożego (1Kor 15, 50). $\mathrm{Za}$ „dzieci Boże zostaną uznani nie ci, którzy są z krwi, z żądzy ciała albo z woli męża, lecz tylko ci, co z Boga się narodzili” (J 1,12-13). Jak w Starym Testamencie przymierzu między Bogiem a Jego ludem towarzyszyło przelanie krwi ofiarnego zwierzęcia, tak też przez krew Jezusa było zawierane nowe przymierze, bo „bez rozlania krwi nie ma odpuszczenia grzechów” (Hbr 9,22). Tylko nieskalanym i czystym życiem można odnowić życie zbezczeszczone grzechem. Ludzie zostali uwolnieni z więzów grzechu za cenę „krwi Chrystusa, jako Baranka niepokalanego i bez zmazy" (1P 1,18-19). Mając na względzie swoją już bliską ofiarę zbawczej śmierci, Jezus, ustanawiając Eucharystię, powiedział: „Ten kielich jest Nowym Przymierzem we Krwi mojej. Czyńcie to, ile razy pić będziecie, na moją pamiątkę" (1Kor 11,25). Krew Chrystusa staje się symbolem całego dzieła odkupienia (Mt 26,28). „Ci, którzy opłukali szaty swoje we krwi Baranka”, będą mogli stanąć przed tronem Boga, służąc Mu we dnie i w nocy w Jego przybytku (Ap 7,14-15).

Podczas sprawowania Eucharystii wierni czczą uroczyście pamięć zbawczego przelania krwi przez Syna Bożego. Postać Zbawiciela, przelewającego swoją krew za grzechy całej ludzkości, pojawia się bardzo często w malarstwie średniowiecznym. Widać to na popularnych obrazach tak zwanego Ecce homo (z koroną cierniową, w szkarłatnym płaszczu), na wizerunkach Ukrzyżowanego, Męża boleści (z wszystkimi śladami cierpienia jako symbolu całego zbawczego dzieła) lub Piety. Zdarzają się także obrazy, na których jest przedstawiany Kościół jako wychodzący — w postaci krwawych promieni — z ran Chrystusa. Legenda o wybłaganiu przez wątpiącego papieża Grzegorza Wielkiego cudu przemiany hostii w krew doprowadziła do pojawiania się w malarstwie motywu tak zwanej mszy świętej gregoriańskiej. Ukazuje ona papieża modlącego się na klęczkach przed ołtarzem, nad którym unosi się Chrystus jako Mąż boleści, a z ran Jego ciała spływa krew wprost do kielicha ${ }^{3}$.

3 Por. M. Lurker, krew, [hasło w:] idem, Stownik obrazów i symboli biblijnych, przeł. K. Romaniuk, Poznań 1989, s. 96-97. 


\section{Starotestamentowe normy dotyczące spożywania krwi}

Według opisu stworzenia świata i człowieka pierwotna dieta ludzkości była wegetariańska: „Oto daję wam wszystkie trawy wydające nasiona, które są na powierzchni całej ziemi, i wszystkie drzewa, których owoce wydają nasiona, niech będą dla was pokarmem" (Rdz 1,29). Rzecz zmieniła się wraz z grzechem pierwszych rodziców, choć informację na ten temat znajdujemy dopiero w kontekście przymierza, które Bóg zawarł z Noem: „Wszystko, co się porusza i żyje, będzie dla was pokarmem, podobnie jak zielone rośliny. To wszystko wam daję" (Rdz 9,3). Stwierdzenie to przywołuje zasady pokarmowe znane z późniejszego prawa (Pwt 14,21; Kpł 11,40). Zmiana zasad żywieniowych nie jest jednak zezwoleniem na okrucieństwo wobec zwierząt ${ }^{4}$. Zezwolenie na spożywanie mięsa zostało obwarowane warunkiem: „Ale nie będziecie jedli mięsa, w którym jest jego życie, to znaczy krew" (Rdz 9,4). Zasady te dotyczą ograniczeń mających na celu ukazanie szacunku do życia jako takiego. Mimo że kontekst wypowiedzi na wskazuje na odniesienie do kultu jedynego Boga, to jednak szacunek dla życia danego przez Stwórcę jest już sam w sobie jakimś aktem oddawania Mu należnej czci. W ten sposób zostaje przygotowana przestrzeń pod późniejsze regulacje dotyczące uboju rytualnego i zasad kultu ${ }^{5}$. W każdym razie zakaz, w jego najbardziej pierwotnej formie, dotyczy dosłownie „,spożywania ciała [bāśs̄rr] wraz z jego życiem [ $b^{e}$ napšô $]$, jego krwią [dāmô]". Różnie interpretowano to stwierdzenie. Jedni sądzili, że w rzeczywistości nie chodzi o spożywanie krwi jako takiej, bo wówczas winno być użyte sformułowanie „pić krew” (Lb 23,24; Pwt 32,42; Iz 49,26; Ez 39,17-18) lub „lizać krew” (1Krl 22,38; Hi 39,30). Chodziłoby raczej o zakaz spożywania mięsa, w którym pulsuje jeszcze krew6. Wydaje się jednak, na co wskazuje wiele innych wypowiedzi, że „krew” utożsamiana jest tu z ,życiem” (Kpł 3,17; 7,26-27; 19,26; Pwt 12,16-24; 1Sm 14,32-34)7. Użyte tu hebrajskie pojęcie nepeš, określające życie, opisuje życiową witalność ciała, a ta związana jest z krwią, która w fizyczny sposób decyduje o tym, że ciało jest żywe. Utożsamienie krwi z życiem jest wręcz naturalne. Ona jest bowiem najbardziej podpadającym pod zmysły nośnikiem życia $(\mathrm{Kpł} 17,11)^{8}$. Starożytni w rzeczywistości

${ }^{4}$ N.M. Sarna, Genesis: The Traditional Hebrew Text with the JPS Translation, Philadelphia 1989, s. 60.

5 J. Lemański, Księga Rodzaju. Wstęp, przekład z oryginatu, komentarz (NKB ST I.1), Częstochowa 2013, s. 413-414.

6 Tak J. Jacob, Das Buch Genesis, Stuttgart 2000, s. 243-244; C. Westermann, Genesis. Kapitel 1-11, Neukirchen-Vluyn 1983, 623.

7 M. Vervenne, 'The Blood is the Life and the Life is the Blood': Blood as Symbol of Life in Biblical Tradition (Gen 9,4), [w:] Ritual and Sacrifice in the Ancient Near East: Proceedings of the International Conference held by the Katholieke Universiteit Leuven from the 17th to the 20th of April 1991, red. J. Quaegebeur, Louvain 1993, s. 469.

8 Ibidem, s. 453. 
nie traktowali krwi jako symbolu życia, lecz uważali je za życie. Szacunek dla życia był wyrazem szacunku do Tego, który je daje. Utożsamienie krwi z życiem wynikało przypuszczalnie z prostej obserwacji. Utrata krwi prowadziła do śmierci. Oprócz tego poza organizmem krew zmieniała kolor, co mogło sugerować, że utraciła coś ze swojej natury ${ }^{9}$. W rzeczywistości jednak chodziło o podkreślenie, że każde życie należy do Boga. Nie sposób jednak wyciągnąć tak daleko idącego wniosku, że skoro życie pochodzi od Boga, a krew stanowi jego widzialny nośnik, to jest ona święta ${ }^{10}$. Przecież wszystko na świecie, jako stworzenie, pochodzi od Boga, a jednak nie zawsze jest święte ${ }^{11}$.

Nieco inne rozporządzenie w sprawie niespożywania krwi zawiera Księga Kapłańska: „Jest to rozporządzenie na wszystkie czasy dla wszystkich waszych pokoleń i we wszystkich waszych siedzibach: Nie będziecie spożywać ani tłuszczu, ani krwi" (Kpł 3,17). Zakaz spożywania tłuszczu, o którym obszernie była mowa w Kpł 3, teraz został połączony z zakazem spożywaniem krwi. Ten ostatni zakaz zostanie bardziej rozwinięty w Kpł 17,10-14. Krew jest tożsama z życiem, a ponieważ ono jest darem Boga, dlatego, jako widoczny znak tego daru, nie może ona być spożywana. Właśnie dlatego winna być zwrócona Dawcy życia. Skropienie ołtarza krwią oznaczało oddanie Bogu życia ofiary ${ }^{12}$. Podobnie zdawkowy zakaz, choć odnoszący się wyłącznie do krwi, znajdujemy na innym miejscu Księgi Kapłańskiej: „W każdym miejscu gdziekolwiek mieszkacie, nie spożywajcie żadnej krwi: ani ptaków, ani bydła. Każdy, kto będzie spożywał jakąkolwiek krew, zostanie wykluczony spośród swojego ludu" (Kpł 7,26-27). Kontekst wskazuje na zakaz spożywania krwi rozciągnięty także na padlinę $(7,24)$ z powodu podejrzenia zbyt małego wykrwawienia się ofiary. W każdym razie powtórzony został całkowity zakaz spożywania krwi. Znacznie obszerniej zagadnienie zostało przedstawione w Kpł 17,10-14. Cała perykopa składa się z dwóch sekcji (ww. 10-12; ww. 13-14), a każda z nich ma strukturę koncentryczną:

A. Zwrócę me oblicze przeciwko temu, kto spożywa krew i usunę go z jego ludu (w. 10b);

B. Życie ciała jest bowiem w jego krwi (w. 11a);

C. Dlatego powiedziałem synom Izraela: Nikomu... nie wolno spożywać krwi (w. 12a);

C'. Dlatego powiedziałem synom Izraela: Nie wolno wam spożywać krwi (w. 14a);

B'. Bo życie ciała jest w jego krwi (w. 14b);

A'. Kto by ją spożył, ma być wykluczony (w. 14c $)^{13}$.

9 J. Lemański, op. cit., s. 414.

10 N.M. Sarna, op. cit., s. 61.

11 W.K. Gilders, The Identification of Blood with „Life”: A Conceptual Foundation?, [w:] idem, Blood Ritual in the Hebrew Bible: Meaning and Power, Baltimore 2004, s. 18.

12 R.E. Clements, Leviticus, Nashville 1970, s. 15.

13 J. Lemański, op. cit., s. 257-258. 
Pierwsza wypowiedź $(17,10-12)$ raz jeszcze powtarza zakaz spożywania krwi: „Jeżeli ktoś z domu Izraela albo spośród przybyszów, którzy wśród was zamieszkali, spożywał jakąkolwiek krew, to zwrócę Moje oblicze przeciwko temu, który spożywał krew i usunę go spośród jego ludu" (w. 10); i to dwukrotnie: „Dlatego powiedziałem do Izraelitów: Nikt z was nie będzie spożywał krwi. Także i przybysz, który wśród was zamieszkał, nie będzie spożywał krwi” (w. 12). W centralnej części wypowiedzi znajduje się uzasadnienie zakazu: „Życie bowiem ciała jest we krwi, a ja dałem ją wam na ołtarz, aby dokonywać nią przebłagania za wasze życie, gdyż krew dokonuje przebłagania za życie" (w. 11). Jest to jedyny tekst, który podaje teologiczne uzasadnienie surowego zakazu spożywania krwi. Stwierdzenie ,życie ciała jest we krwi” wskazuje na znany nam już fakt, że krew zawiera w sobie istotę życia. Przekonanie to znajduje swoje odzwierciedlenie w religijnej myśli Mezopotamii, gdzie uważano, że człowiek został stworzony $\mathrm{z}$ rozlanej krwi bóstwa ${ }^{14}$. Uroczysta deklaracja ,ja dałem ją wam” wskazuje na to, że sam Bóg dał taką moc krwi ofiarnej. Zatem zakaz spożywania krwi znajduje swoje uzasadnienie w odkupieńczej mocy ołtarza ofiarnego (,aby dokonywać nią przebłagania za wasze życie”, w. 11c) $)^{15}$. Ludzie niemal od zawsze uświadamiali sobie, że śmierć następuje wraz z ustaniem oddechu (hebr. nepeš) lub utratą krwi (hebr. dām). Pierwotne znaczenie pojęcia nepeš to „gardło” (zob. na przykład Iz 32,$6 ; 58,10)$. Ponieważ gardło jest początkiem zarówno przewodu pokarmowego, jak i oddechowego, to właśnie dlatego analizowane pojęcie zyskuje znaczenie „apetyt”, a także „oddech, życie” (zob. Joz 2,13; 1Krl 19,10; Ez 13,19). Takie przejście od znaczenia „gardło” do ,życie”, mogło się dokonać również między pojęciami nepeš a dām, substancją życiodajną organizmu ${ }^{16}$. Zatem nie krew, jako taka, nie ma być spożywana, lecz to, co ona oznacza, a więc siła życiodajna. Krew jako siedziba życia nie może być w żaden sposób profanowana (zob. Rdz 10,11), bo ona jest wyłączną własnością JHWH, Dawcy życia ${ }^{17}$.

Druga wypowiedź $(17,13-14)$ wskazuje na fakt, że można było spożywać dziczyznę czystych zwierząt i ptaków, pod warunkiem że ich krew zostanie wylana i przykryta ziemią: ,Jeżeli ktokolwiek z Izraelitów albo przybyszów, którzy wśród was zamieszkali, upolował zwierzę lub ptaka, które wolno spożywać, niech wyleje jego krew i przykryje ziemią" (w. 13; por. Rdz 4,10). Obowiązuje tu to samo prawo, o którym była mowa wcześniej: ponieważ wszelkie życie należy do JHWH, który go udziela (por. Ps 104,29-30), również krew, jako siedziba życia, winna być Jemu zwrócona ${ }^{18}$.

14 J.H. Walton, V.H. Matthews, M.W. Chavales, Komentarz historyczno-kulturowy do Biblii Hebrajskiej, przeł. Z. Kościuk, red. wyd. pol. W. Chrostowski, Warszawa 2000, s. 130.

15 J. Milgrom, Leviticus 17-22: A New Translation with Introduction and Commentary, New York 2000, 1472.

16 J. Lemański, op. cit., s. 256.

17 J.E. Hartley, Leviticus, Dallas 1992, s. 277.

18 J. Lemański, op. cit., s. 258. 
W sprawie diety wykluczającej krew wypowiedział się też autor Księgi Powtórzonego Prawa: „Tylko krwi nie będziecie jedli, wylejecie ją na ziemię jak wodę” (Pwt 12,16); „Tylko bądź wytrwały, abyś nie jadł krwi, ponieważ we krwi jest życie. Nie będziesz jadł życia z mięsem” (Pwt 12,23). Wraca temat ,jedzenia" (hebr. 'ākal) krwi, co wskazuje nie tyle na picie krwi jako takiej, ile na spożywanie mięsa, które nie zostało we właściwy sposób wykrwawione. Polecenie wylania krwi na ziemię przypomina dyspozycję Kpł 17,13. Uzasadnienie „ponieważ we krwi jest życie" (Pwt 12,23b) z jednej strony wskazuje na motyw znany z literatury religijnej z Ugarit i Mezopotamii, w której krew ukazywana była jako życiowa siła zwierzęcia ${ }^{19}$. Z drugiej strony, uzasadnienie to wskazuje na panujące w judaizmie przekonanie, że człowiek rodzi się w wodzie i krwi, i właśnie krew jest konieczna, aby życie było kontynuowane. Poza tym życie, powiązane z symboliką krwi, jest dziełem stwórczym Boga. Więcej, życie jest jednym z elementów natury Boga. Wyciągając rękę po krew, człowiek wyciąga rękę w kierunku Boga, a nawet występuje przeciw Niemu. A to skutkowało wykluczeniem ze społeczności ${ }^{20}$.

Podsumowując, zauważamy, że zakaz spożywania krwi, powszechny w Starym Testamencie, opierał się na uważnej obserwacji życia ludzkiego. Z jednej strony dostrzegano, że utrata krwi skutkuje śmiercią. Z tego doświadczenia wyciągnięto wniosek, że w krwi musi znajdować się jakaś zasada życia, skoro nie niej stworzenie nie może żyć. Z drugiej strony życie było wyłącznym darem, a nawet naturą samego Boga, dlatego ono całkowicie do Niego należało. Wyciągnięcie ręki po krew, zasadę życia, było wystąpieniem przeciw samemu Bogu. Tak rzecz się miała w doświadczeniu ówczesnej ludzkości. Rzecz zmienia się w Nowym Testamencie, dlatego do tej części Biblii sięgniemy teraz.

\section{Nowotestamentowe normy dotyczące spożywania krwi}

Nowy Testament zdaje się podtrzymywać postanowienia prawodawcy Starego Testamentu. Świadczy o tym dyskusja podjęta na tak zwanym Soborze Jerozolimskim, którego postanowienia zostały przedstawione w formie Klauzul Jakubowych: „Dlatego ja sądzę, że nie należy nakładać ciężarów na pogan, nawracających się do Boga, lecz napisać im, aby się wstrzymali od pokarmów ofiarowanych bożkom, od nierządu, od tego, co uduszone, i od krwi [gr. kai tou haimatos]" (Dz 15,20). Zakaz spożywania krwi, będącej siedliskiem życia, którego wyłącznym panem jest Bóg, zostało sformułowane bardzo radykalnie, jak zauważyliśmy,

19 J.H. Walton, V.H. Matthews, M.W. Chavales, op. cit., s. 189.

20 A.J. Wrider, Water, Fire, and Blood: Defilement and Purification from a Ricoeurian Perspective, „Anglican Theological Review” 67, 1985, nr 2, s. 142. 
już w Starym Testamencie (Rdz 9,4; Kpł 17,10-14)21. Celem zachowania tych praw było to, by poganie, nawróceni na chrześcijaństwo, unikali postępowania, które mogło narazić na szwank wrażliwość nawróconych Hebrajczyków. Mieli również wyrazić w ten sposób dobrą wolę i troskę o jedność wewnątrz samej wspólnoty, szczególnie podczas zgromadzeń liturgicznych ${ }^{22}$.

Nowe światło na zakaz spożywania krwi rzuca odwołanie się do Klauzul Jakubowych w postanowieniach Soboru Jerozolimskiego: „Postanowiliśmy bowiem, Duch Święty i my, nie nakładać na was żadnego ciężaru oprócz tego, co konieczne. Powstrzymajcie się od ofiar składanych bożkom, od krwi [gr. kai haimatos], od tego, co uduszone, i od nierządu. Dobrze uczynicie, jeżeli powstrzymacie się od tego. Bywajcie zdrowi!" (Dz 15,28-29). Klauzule te miały charakter dyscyplinarny, a nie doktrynalny, i ograniczony zasięg terytorialny (zob. Dz 15,23). Szczególnie znaczenie w tym kontekście ma zdanie: „Dobrze uczynicie, jeżeli powstrzymacie się od tego" (Dz 15,29). Nie był to więc nakaz w celu osiągnięcia zbawienia, lecz jedynie zalecenie mające ułatwić wiernym życie w pokoju i wzajemnej zgodzie, zwłaszcza w społeczności Kościoła złożonej z chrześcijan pochodzenia zarówno żydowskiego, jak i pogańskiego ${ }^{23}$.

Wizyta Pawła w Jerozolimie pod koniec swojej działalności i przypomnienie decyzji Soboru Jerozolimskiego potwierdza ograniczony ich zasięg: „Co zaś do pogan, którzy uwierzyli, posłaliśmy im na piśmie polecenie, aby powstrzymali się od pokarmów ofiarowanych bożkom, od krwi, od tego, co uduszone, i od nierządu" (Dz 21,25). Rzecz wciąż dotyczy pogan, na których nie miały być nakładane zbędne ciężary, jednak zakaz spożywania krwi został im zalecony. To przypomnienie w Dz 21,25 pojawiło się w kontekście kontrowersji dotyczących zachowania lub nie Prawa przez Pawła i jego towarzyszy (Dz 21,20-26). Ostatecznie Paweł zgodził się na decyzję Jakuba i poddał się wraz z towarzyszami oczyszczeniu (w. 26). Działanie owo wyraźnie wskazuje na lokalny zasięg zalecenia niespożywania krwi i innych przepisów Prawa. Jeśli miałoby się pojawić zgorszenie, to do jego uniknięcia zachowywano te zalecenia Soboru Jerozolimskiego.

\section{Wnioski}

Polecenie „Dobrze uczynicie, jeżeli powstrzymacie się od tego" (Dz 15,29) nie było nakazem w celu osiągnięcia zbawienia, lecz jedynie zaleceniem mającym ułatwić wiernym życie w pokoju i wzajemnej zgodzie, zwłaszcza w społeczności Kościoła złożonej z chrześcijan pochodzenia zarówno żydowskiego, jak i pogań-

21 A. Jankowski, K. Romaniuk, L. Stachowiak, Komentarz praktyczny do Nowego Testamentu, Poznań-Warszawa 1975, s. 578.

22 S. Stasiak, Komentarz teologiczno-pastoralny do Biblii Tysiaclecia. Nowy Testament. Dzieje Apostolskie, List do Rzymian, 1-2 List do Koryntian, List do Galatów, Poznań 2014, s. 151.

${ }^{23}$ Ibidem, s. 153. 
skiego. Słowa zaś „Co zaś do pogan, którzy uwierzyli, posłaliśmy im na piśmie polecenie, aby powstrzymali się od pokarmów ofiarowanych bożkom, od krwi, od tego, co uduszone, i od nierządu" (Dz 21,25) wskazują wyraźnie na lokalny zasięg zalecenia niespożywania krwi i innych przepisów Prawa. Jeśli miałoby się pojawić zgorszenie, to do jego uniknięcia zachowywano te zalecenia Soboru Jerozolimskiego. W naszej więc ocenie bezkrwawa dieta nie jest absolutnym nakazem prawnym, przynajmniej dla chrześcijan. Można go jedynie uznać za pewne zalecenie podyktowane względami społecznymi i terytorialnymi.

\section{Bibliografia}

Clements R.E., Leviticus, Nashville 1970.

Drozd J., Ostatnia Wieczerza nowa Pascha (Attende Lectioni IV), Katowice 1977.

Gilders W.K., The Identification of Blood with „Life”: A Conceptual Foundation?, [w:] idem, Blood Ritual in the Hebrew Bible: Meaning and Power, Baltimore 2004.

Hartley J.E., Leviticus, Dallas 1992.

Jacob J., Das Buch Genesis, Stuttgart 2000.

Jankowski A., Romaniuk K., Stachowiak L., Komentarz praktyczny do Nowego Testamentu, Poznań-Warszawa 1975.

Kopaliński W., Stownik symboli, Warszawa ${ }^{2} 1990$.

Lemański J., Księga Rodzaju. Wstęp, przekład z oryginału, komentarz (NKB ST I.1), Częstochowa 2013.

Lurker M., Słownik obrazów i symboli biblijnych, przeł. K. Romaniuk, Poznań 1989.

Milgrom J., Leviticus 17-22: A New Translation with Introduction and Commentary, New York 2000. Sarna N.M., Genesis: The Traditional Hebrew Text with the JPS Translation, Philadelphia 1989.

Stasiak S., Komentarz teologiczno-pastoralny do Biblii Tysiaclecia. Nowy Testament. Dzieje Apostolskie, List do Rzymian, 1-2 List do Koryntian, List do Galatów, Poznań 2014.

Vervenne M., 'The Blood is the Life and the Life is the Blood': Blood as Symbol of Life in Biblical Tradition (Gen 9,4), [w:] Ritual and Sacrifice in the Ancient Near East: Proceedings of the International Conference held by the Katholieke Universiteit Leuven from the 17th to the 20th of April 1991, red. J. Quaegebeur, Louvain 1993.

Walton J.H., Matthews V.H., Chavales M.W., Komentarz historyczno-kulturowy do Biblii Hebrajskiej, przeł. Z. Kościuk, red. wyd. pol. W. Chrostowski, Warszawa 2000.

Westermann C., Genesis. Kapitel 1-11, Neukirchen-Vluyn 1983.

Wrider A.J., Water, Fire, and Blood. Defilement and Purification from a Ricoeurian Perspective, „Anglican Theological Review” 67, 1985, nr 2.

Ekonomia - Wroclaw Economic Review 24/4 (2018)

(C) for this edition by CNS 